Note

\section{Micro-spot Assay and Detection on Polyacrylamide Gel of Mung Bean Endopeptidase Activity by Substrate-Polyacrylamide Gel Plate Method}

\section{Wataru Mitsuhashi, Tomokazu KoshibA and Takao MinamiKawA}

Department of Biology, Tokyo Metropolitan University, Setagaya-ku, Tokyo 158, Japan

Received March 23, 1984

Several kinds of plant endopeptidase such as sulfhydryl, acidic, and serine proteinases have been known to occur during the degradation of storage proteins in germinating seeds and other metabolic processes. ${ }^{1,2)}$ Assay methods and detection on the gel after electrophoresis for the endopeptidase have been faced with many difficulties. In recent years, a number of analytical methods have been reported to detect or quantitate endopeptidase activity. $^{3 \sim 8)}$ In this paper, using identical substratepolyacrylamide gel plates both a quantitative micro-assay and a detection on the gel were performed.

Vigna mungo seeds were germinated in the dark at $27 \sim 28^{\circ} \mathrm{C}$. Cotyledons (15 pairs) of 3-day-old seedlings were homogenized with $6 \mathrm{ml}$ of $50 \mathrm{~mm}$ Tris- $\mathrm{HCl}$ buffer ( $\mathrm{pH}$ 7.4) containing $10 \mathrm{~mm} 2$-mercaptoethanol (2-ME) in a cold mortar. The homogenate was centrifuged and the super- natant solution was dialyzed against $50 \mathrm{~mm}$ sodium acetate buffer ( $\mathrm{pH} 5.4$ ) containing $10 \mathrm{~mm}$ 2-ME. After centrifugation the clarified solution was used as a crude mung bean endopeptidase. The substrate-polyacrylamide gel plates were made with $7.5 \%$ polyacrylamide and gelatin $(1 \%)$, azocasein $(2 \%)$ or hemoglobin $(1 \%)$ dissolved in water, with $0.3 \mathrm{~mm}$ thickness and $11 \times 11 \mathrm{~cm}$ size.

Ten $\mu 1$ of the enzyme solutions were spotted on the plate and incubated at $30^{\circ} \mathrm{C}$. After an appropriate reaction time, the plate was dyed with $1 \%$ Amido black solution for $30 \mathrm{~min}$ and destained with $7.5 \%$ acetic acid overnight. The proteolytic activity on the plate was detected as a clear zone against a blue background (Fig. 1). Optical density of the transparent zone against a blue background was

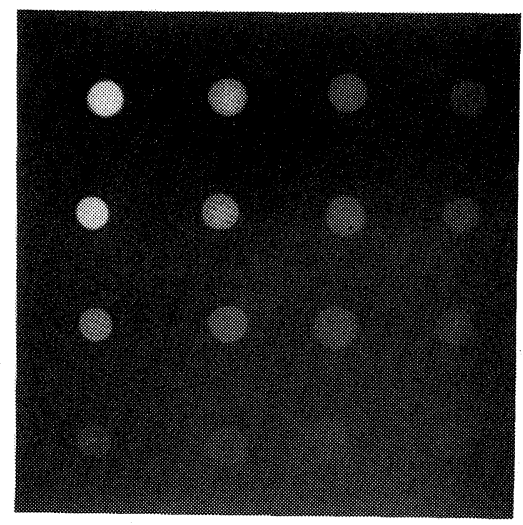

FIG. 1. Typical Spots of Endopeptidase Activity on a Gelatin-Polyacrylamide Gel Plate.

Ten $\mu \mathrm{l}$ of mung bean endopeptidase were spotted on the plate at various concentrations and incubated for $40 \mathrm{~min}$ at $30^{\circ} \mathrm{C}$. Detailed procedure is described in the text.

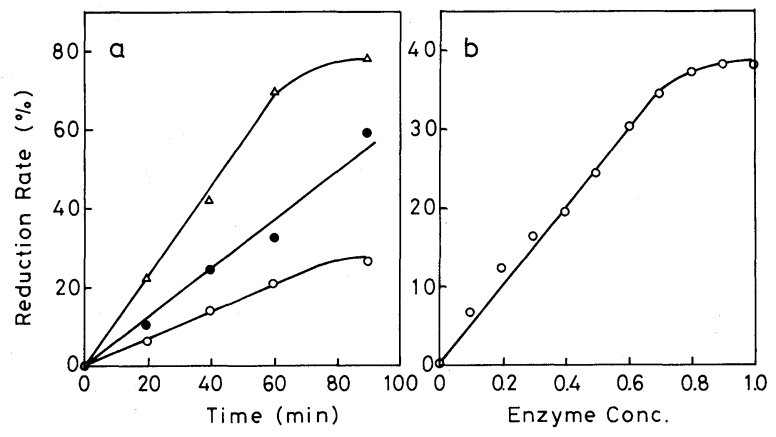

FIG. 2. Time and Dose-response Curves of Mung Bean Endopeptidase Activity as Measured by the Gelatin-Polyacrylamide Gel Plate Method.

Ten $\mu$ l of enzyme solutions were spotted on the plate and incubated for an appropriate time (a) or for $40 \mathrm{~min}$ (b) at $30^{\circ} \mathrm{C}$. For experimental details see the text.

a: Relationship between reaction time and activity. Crude $(-\triangle-), \times 0.5$ diluted $(--)$ and $\times 0.25$ diluted (- $\mathrm{O}-$ ) enzyme solutions were used.

b: Relationship between enzyme concentration and activity. Enzyme concentrations were defined as dilution rate of crude enzyme solution. 

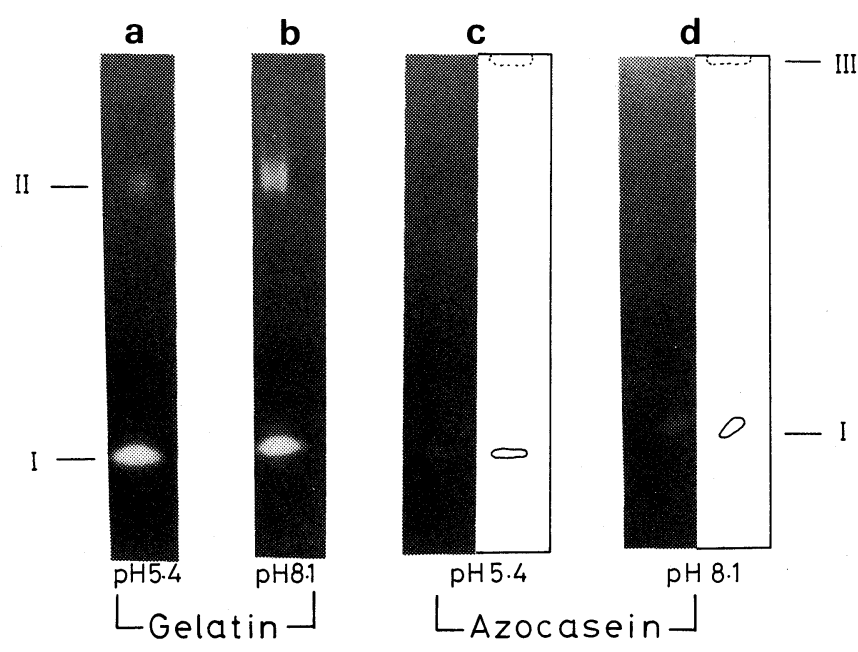

FIG. 3. Polyacrylamide Slab Gel Zymogram Patterns of Mung Bean Endopeptidases.

After crude enzymes were separated by electrophoresis according to Davis' system, the gel was incubated with gelatin plate or azocasein plate $(\mathrm{pH} 5.4$ or 8.1$)$ for $120 \mathrm{~min}$ at $30^{\circ} \mathrm{C}$. Details are given in the text.

measured at $525 \mathrm{~nm}$ by a quick scan densitometer ( $\mathrm{R} \& \mathrm{D}$, Helena Laboratories, Beaumont, Tex.). The baseline and maximum values of optical density were set with an opaque area of no enzyme activity and with a clear area of glass plate, respectively. The height of the reduced peak on the chart paper was calculated as the percentage of the reducing rate of optical density against that of no enzyme background. When the gelatin plate was used, relatively linear relationships were observed with reduction vs time and vs dose of the mung bean enzyme (Fig. 2a and b). Linear regions were obtained in the range from 0 to $70 \%$ reduction rate against time, and under $35 \%$ reduction rate against dose. Papain $(0.4 \sim 2.5 \mu \mathrm{g} / \mathrm{ml})$ also showed a fine relationship with time and dose, but pepsin and trypsin did not show such clear relationships between the amounts of the activities and the degree of substrate digestion (data not shown). When hemoglobin or azocasein plates were used, the background became too high to measure the activity because these substrates tend to diffuse out from the gel plate.

Detection of endopeptidase activity after polyacrylamide gel electrophoresis was performed by the following procedures. After electrophoresis with Davis' system ( $\mathrm{pH}$ 9.5) using $9 \%$ polyacrylamide ${ }^{7)}$ the gel was immersed in $1 \mathrm{~m}$ sodium acetate buffer, $\mathrm{pH} 5.4$, or $1 \mathrm{M}$ Tris- $\mathrm{HCl}$ buffer, $\mathrm{pH} 8.1$, containing $10 \mathrm{~mm} 2-\mathrm{ME}$ for $5 \sim 10 \mathrm{~min}$ at room temperature. The gel was placed on the substrate-gel plate and incubated at $30^{\circ} \mathrm{C}$ for $120 \mathrm{~min}$. The plate was stained as above. The clear band region was visualized against a blue background under permeating light. With this meth- od using gelatin- and azocasein-gel plates three major bands (I, II, and III) were detected at pH 5.4 and 8.1 in a mung bean extract (Fig. 3). This shows that the activity of band I hydrolyzes both substrates of gelatin and azocasein but the activities of band II and III little hydrolyze azocasein and gelatin, respectively. Trypsin and papain were detectable by this method, but broad bands were observed as compared with mung bean enzymes.

\section{REFERENCES}

1) J. D. Bewley and M. Black, "Physiology and Biochemistry of Seeds in Relation to Germination", Vol. 1, Springer-Verlag, Berlin, 1978, pp. 177 279 .

2) C. A. Ryan and M. Walker-Simmons, "The Biochemistry of Plants," Vol. 6, ed. by A. Marcus, Academic Press, New York, 1981, pp. $321 \sim 350$.

3) K. Santarius and C. Ryan, Anal. Biochem., 77, 1 (1977).

4) T. L. Brown, M-G. Yet and F. Wold, Anal. Biochem., 122, 164 (1982).

5) O. Vesterberg and R. Eriksson, Biochim. Biophys. Acta, 285, 393 (1972).

6) J. L. Westergaard, C. Hackbarth, M. W. Treuhaft and R. C. Roberts, J. Immunol. Methods, 34, 167 (1980).

7) T. Koshiba and T. Minamikawa, Plant \& Cell Physiol., 21, 865 (1980).

8) D. Every, Anal. Biochem., 116, 519 (1981). 